\title{
Genome sequence of Ensifer arboris strain LMG 14919ª microsymbiont of the legume Prosopis chilensis growing in Kosti, Sudan
}

\author{
Wayne Reeve $^{1 *}$, Rui Tian ${ }^{1}$, Lambert Bräu ${ }^{2}$, Lynne Goodwin ${ }^{3}$, Christine Munk ${ }^{3}$, Chris Detter ${ }^{3}$, \\ Roxanne Tapia ${ }^{3}$, Cliff Han ${ }^{3}$, Konstantinos Liolios ${ }^{4}$, Marcel Huntemann ${ }^{4}$, Amrita Pati ${ }^{4}$, Tanja \\ Woyke $^{4}$, Konstantinos Mavrommatis ${ }^{5}$, Victor Markowitz ${ }^{5}$, Natalia Ivanova ${ }^{4}$, Nikos Kyrpides ${ }^{4}$ \\ \& Anne Willems ${ }^{6}$. \\ ${ }^{1}$ Centre for Rhizobium Studies, Murdoch University, Western Australia, Australia \\ ${ }^{2}$ School of Life and Environmental Sciences, Deakin University, Victoria, Australia \\ ${ }^{3}$ Los Alamos National Laboratory, Bioscience Division, Los Alamos, New Mexico, USA \\ ${ }^{4}$ DOE Joint Genome Institute, Walnut Creek, California, USA \\ ${ }^{5}$ Biological Data Management and Technology Center, Lawrence Berkeley National \\ Laboratory, Berkeley, California, USA \\ ${ }^{6}$ Laboratory of Microbiology, Department of Biochemistry and Microbiology, Faculty of \\ Sciences, Ghent University, Belgium \\ *Correspondence: Wayne Reeve (W.Reeve@murdoch.edu.au)
}

Keywords: root-nodule bacteria, nitrog en fixation, rhizobia, Alphaproteobacteria

Ensifer arboris LMG $14919^{\top}$ is an aerobic, motile, Gram-negative, non-spore-forming rod that can exist as a soil saprophyte or as a legume microsymbiont of several species of legume trees. LMG $14919^{\top}$ was isolated in 1987 from a nodule recovered from the roots of the tree Prosopis chilensis growing in Kosti, Sudan. LMG $14919^{\top}$ is highly effective at fixing nitrogen with P. chilen sis (Chilean mesquite) and Acacia senegal (gum Arabic tree or gum acacia). LMG $14919^{\top}$ does not nodulate the tree Leucena leucocephala, nor the herbaceous species Macroptilium atropurpureum, Trifolium pratense, Medicago sativa, Lotus corniculatus and Galega orientalis. Here we describe the features of $E$. arboris LMG $14919^{\top}$, together with genome sequence information and its annotation. The 6,850,303 bp high-quality-draft genome is arranged into 7 scaffolds of 12 contigs containing 6,461 protein-coding genes and 84 RNA-only encoding genes, and is one of 100 rhizobial genomes sequenced as part of the DOE Joint Genome Institute 2010 Genomic Encyclopedia for Bacteria and Archaea-Root Nodule Bacteria (GEBA-RNB) project.

\section{Introduction}

Legume plants form nitrogen fixing symbiosis with root nodule bacteria, collectively called rhizobia. These legumes are particularly useful crop plants that do not require exogenous nitrogenous fertilizer to support growth in less fertile, nitrogen-deficient conditions. They include some of our staple food and feed plants such as beans, peas, soybeans, lentils, clover, peanuts and alfalfa and are mostly annual crops. In many arid and savannah regions, leguminous trees represent a particularly valuable resource as they are often deep-rooted and drought resistant. They have been used traditionally in the Sahel region as sources of timber, fodder and for soil improvement [1]. Prosopis chilensis, also known as Chilean mesquite, is a native tree from South America that has many uses: its nutritious pods can be ground to produce flour and are also eaten by livestock; its wood is used for construction and furniture. Chilean mesquite is also used for intercropping 
with other plants, for which it provides shelter and nutrients (leaf compost, nitrogen). Acacia senegal (recently renamed as Senegalia senegal) is a plant of particular importance in the production of gum arabic in the Sahel region and the Middle East. Its seeds are dried for human consumption, and its leaves and pods serve as feed for sheep, goats and camels. The plant is also used in agroforestry in intercropping with watermelon and grasses, and in rotation systems with other crops (Agroforestree Database [2]).

The microsymbiont of these legume trees from Sudan and Kenya [3] has been renamed as Ensifer arboris [4], of which LMG 14919' (= HAMBI 1552, ORS 1755, TTR38) is the type strain. This strain was isolated from root nodules of Prosopis chilensis from Kosti, Sudan, and shown to effectively nodulate its original host as well as Acacia senegal [5].

Given the drought tolerance of the host trees, it seems fitting that their symbionts are also stress resistant: Ensifer arboris was described as tolerant to temperatures up to $41-43^{\circ} \mathrm{C}, 3 \% \mathrm{NaCl}$, several heavy metals (including $\mathrm{Pb}, \mathrm{Cd}, \mathrm{Hg}, \mathrm{Cu}$ ) and a wide range of antibiotics $[3,5]$, characteristics that contribute to the success of the rhizobial-legume tree association in challenging environmental conditions [6]. Here we present a summary classification and a set of features for E. arboris strain LMG $14919^{\mathrm{T}}$ (Table 1), together with the description of the complete genome sequence and its annotation.

\section{Classification and features}

E. arboris LMG $14919^{\mathrm{T}}$ is a motile, nonsporulating, non-encapsulated, Gram-negative rod in the order Rhizobiales of the class Alphaproteobacteria. The rod-shaped form varies in size with dimensions of approximately $0.25 \mu \mathrm{m}$ in width and 1.0-1.5 $\mu \mathrm{m}$ in length (Figure 1, Left and Center). The strain is fast-growing, forming colonies within 3-4 days when grown on half strength Lupin Agar ( $1 / 2 \mathrm{LA})$ [19], tryptone-yeast extract agar (TY) [20] or a modified yeastmannitol agar (YMA) [21] at $28^{\circ} \mathrm{C}$. Colonies on $1 / 2$ LA are white-opaque, slightly domed and moderately mucoid with smooth margins (Figure 1 Right).

E. arboris LMG $14919^{\mathrm{T}}$ is capable of using several amino acids, including L-proline, L-arginine, sodium glutamate and L-histidine as sole nitrogen sources and can use a wide range of different carbon sources including L-arabinose, D-galactose, raffinose, L-rhamnose, maltose, lactose, Dfructose, D-mannose, trehalose, D-ribose, xylene, methyl-D-mannoside, sorbitol, dulcitol, mesoinositol, inulin, dextrin, amygdalin, arbutin, sodium citrate, itaconate, $\alpha$-ketoglutarate, sodium maltose, 1,2-propylene glycol, and 1,2-butylene glycol [5].

Minimum Information about the Genome Sequence (MIGS) is provided in Table 1. Figure 2 shows the phylogenetic neighborhood of $E$. arboris LMG $14919^{\mathrm{T}}$ in a 16S rRNA sequence based tree. This strain shares 99\% (1361/1366 bp) and 99\% $(1361 / 1366 \mathrm{bp})$ sequence identity to the $16 \mathrm{~S}$ rRNA of the fully sequenced E. meliloti Sm1021 [26] and E. medicae WSM419 [27] strains, respectively.
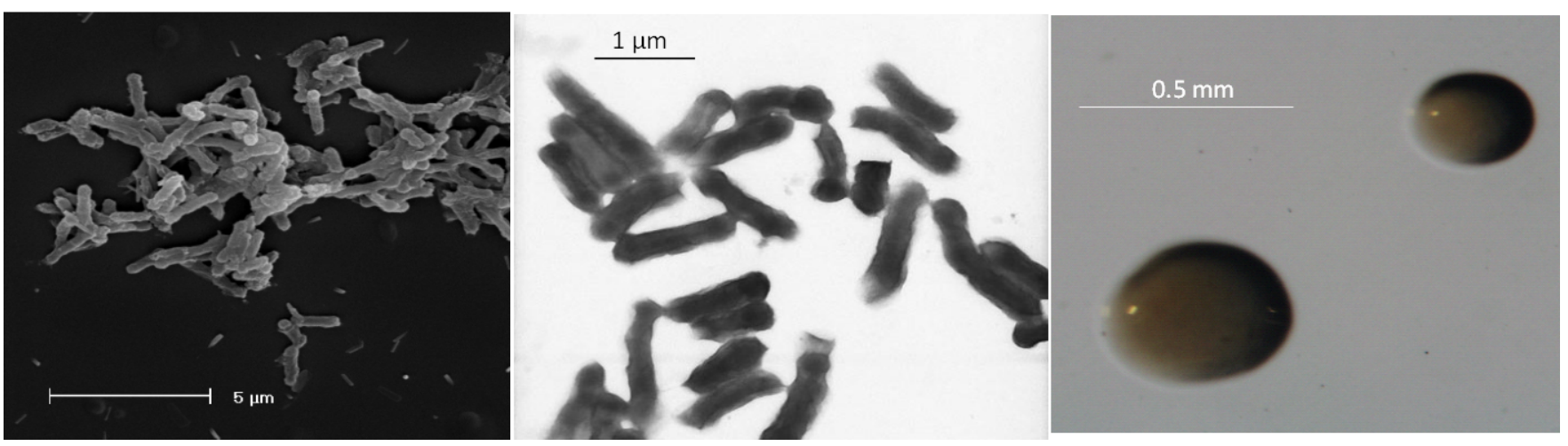

Figure 1. Images of Ensifer arboris LMG $14919^{\top}$ using scanning (Left) and transmission (Center) electron microscopy and the appearance of colony morphology on a solid medium (Right). 
Table 1. Classification and general features of Ensifer arboris LMG $14919^{\top}$ according to the MIGS recommendations [7]

\begin{tabular}{|c|c|c|c|}
\hline MIGS ID & Property & Term & Evidence code \\
\hline & \multirow{8}{*}{ Current classification } & Domain Bacteria & TAS [8] \\
\hline & & Phylum Proteobacteria & TAS [9] \\
\hline & & Class Alphaproteobacteria & TAS $[10,11]$ \\
\hline & & Order Rhizobiales & TAS $[11,12]$ \\
\hline & & Family Rhizobiaceae & TAS $[13,14]$ \\
\hline & & Genus Ensifer & TAS $[4,15,16]$ \\
\hline & & Species Ensifer arboris & TAS [4] \\
\hline & & Strain LMG $14919^{\top}$ & \\
\hline & Gram stain & Negative & IDA \\
\hline & Cell shape & Rod & IDA \\
\hline & Motility & Motile & IDA \\
\hline & Sporulation & Non-sporulating & NAS \\
\hline & Temperature range & Mesophile & NAS \\
\hline & Optimum temperature & $28^{\circ} \mathrm{C}$ & NAS \\
\hline & Salinity & Non-halophile & NAS \\
\hline \multirow[t]{3}{*}{ MIGS-22 } & Oxygen requirement & Aerobic & TAS [3] \\
\hline & Carbon source & Varied & TAS [5] \\
\hline & Energy source & Chemoorg anotroph & NAS \\
\hline MIGS-6 & Habitat & Soil, root nodule, on host & $\operatorname{TAS}[3,5]$ \\
\hline MIGS-15 & Biotic relationship & Free living, symbiotic & TAS $[3,5]$ \\
\hline \multirow[t]{3}{*}{ MIGS-14 } & Pathog enicity & Non-pathog enic & NAS \\
\hline & Biosafety level & 1 & TAS [17] \\
\hline & Isolation & Root nodule & TAS [5] \\
\hline MIGS-4 & Geographic location & Kosti, Sudan & TAS [5] \\
\hline MIGS-5 & Soil collection date & 1987 & IDA \\
\hline MIGS-4. 1 & Long itude & 32.66342 & TAS [5] \\
\hline MIGS-4.2 & Latitude & 13.16125 & TAS [5] \\
\hline MIGS-4. 3 & Depth & Not reported & NAS \\
\hline MIGS-4.4 & Altitude & Not reported & NAS \\
\hline
\end{tabular}

Evidence codes - IDA: Inferred from Direct Assay; TAS: Traceable Author Statement (i.e., a direct report exists in the literature); NAS: Non-traceable Author Statement (i.e., not directly observed for the living, isolated sample, but based on a generally accepted property for the species, or anecdotal evidence). These evidence codes are from the Gene Ontology project [18]. 


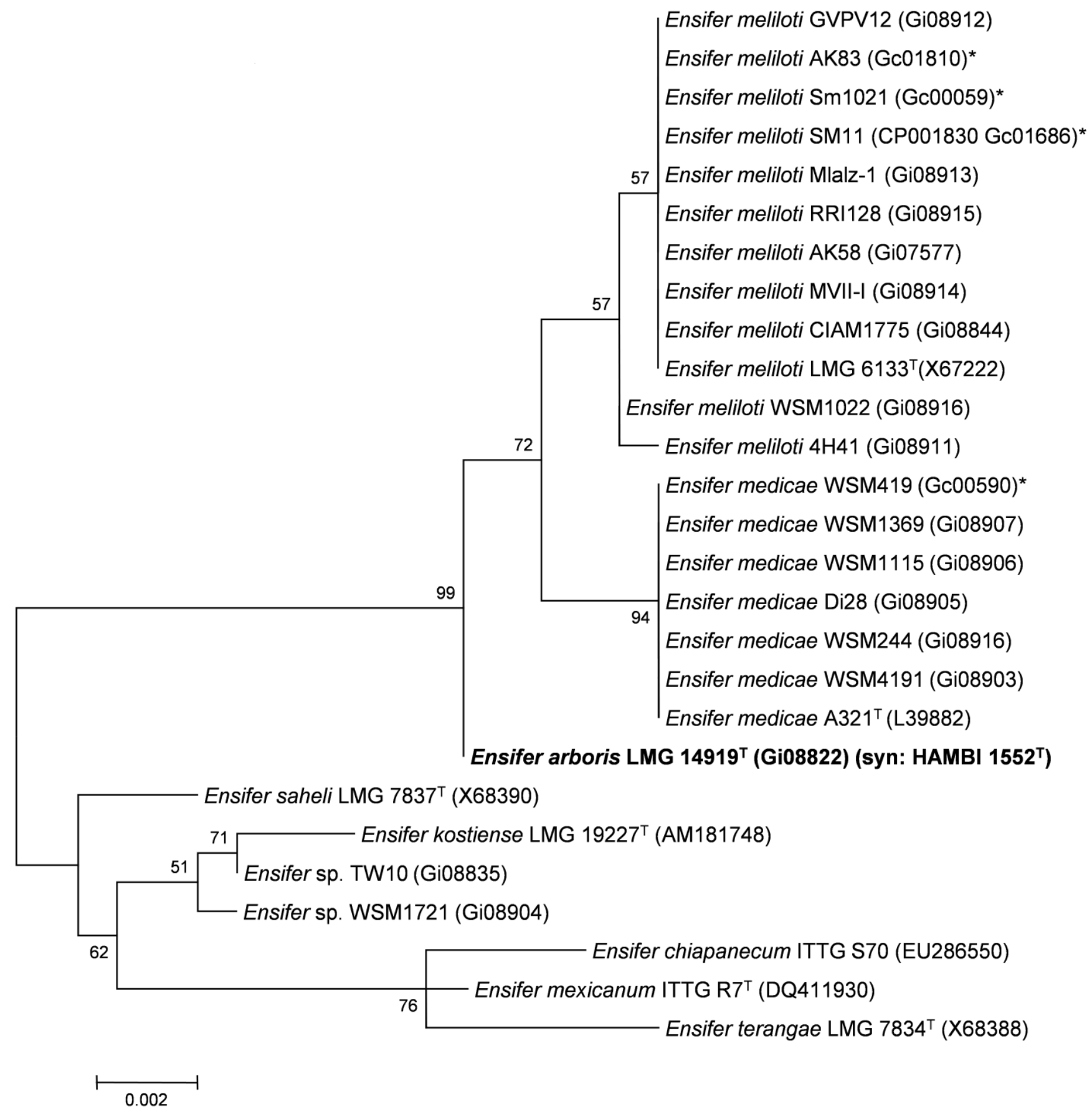

Figure 2. Phylogenetic tree showing the relationship of Ensifer arboris LMG $14919^{\top}$ (shown in bold print) to other Ensifer spp. in the order Rhizobiales based on aligned sequences of the 16S rRNA gene (1,290 bp internal region). All sites were informative and there were no gap-containing sites. Phylogenetic analyses were performed using MEGA, version 5 [22]. The tree was built using the Maximum-Likelihood method with the General Time Reversible model [23]. Bootstrap analysis [24] with 500 replicates was performed to assess the support of the clusters. Type strains are indicated with a superscript T. Brackets after the strain name contain a DNA database accession number and/or a GOLD ID (beginning with the prefix G) for a sequencing project registered in GOLD [25]. Published genomes are indicated with an asterisk. 


\section{Symbiotaxonomy}

E. arboris LMG $14919^{\mathrm{T}}$ was initially shown to form nodules $\left(\mathrm{Nod}^{+}\right)$and fix nitrogen $\left(\mathrm{Fix}^{+}\right)$with two leguminous tree species, $P$. chilensis and $A$. senegal. It was unable to elicit nodules on the herbaceous perennials Macroptilium atropurpureum, Trifolium pratense, Medicago sativa, Lotus corniculatus and Galega orientalis [5]. The symbiotic properties of this strain in seedlings of Acacia and Prosopis spp. in Sudan and Senegal have been reported in detail [6]. Indeterminate nodul es are induced, mainly on the lateral roots either in clusters or individually. Young nodules are spherical and later become elongated and are commonly branched. LMG 14919 (=HAMBI 1552) was shown to nodulate and fix nitrogen in seedlings of African A. mellifera, $A$. nilotica, $A$ oerfota (synonym $A$. nubica), $A$. senegal, A. seyal, A. sieberiana, A. tortilis subsp. raddiana, Latin American $A$. angustissima, $P$. chilensis and P. pallida, and Afro-Asian P. cineraria. It also effectively nodulates with Latin-American introductions of $P$. chilensis and P. juliflora in Africa [6]. It induced small ineffective nodules on Australian A. holosericea and African P. africana [6].

\section{Genome sequencing and annotation Genome project history}

This organism was selected for sequencing on the basis of its environmental and agricultural relevance to issues in global carbon cycling, alternative energy production, and biogeochemical importance, and is part of the Community Sequencing Program at the U.S. Department of Energy, Joint Genome Institute (JGI) for projects of relevance to agency missions. The genome project is deposited in the Genomes OnLine Database [25] and an improved-high-quality-draft genome sequence in IMG. Sequencing, finishing and annotation were performed by the JGI. A summary of the project information is shown in Table 2.

\section{Growth conditions and DNA isolation}

E. arboris LMG $14919^{\mathrm{T}}$ was cultured to mid logarithmic phase in $60 \mathrm{ml}$ of TY rich medium on a gyratory shaker at $28^{\circ} \mathrm{C}$ [28]. DNA was isolated from the cells using a CTAB (Cetyl trimethyl ammonium bromide) bacterial genomic DNA isolation method [29].

\section{Genome sequencing and assembly}

The genome of Ensifer arboris LMG 14919' was sequenced at the Joint Genome Institute (JGI) using Illumina technology [30]. An Illumina shortinsert paired-end library with an average insert size of 270 bp generated 19,256,666 reads and an Illumina long-insert paired-end library with an average insert size of 9,232.94 +/- 2,530.88 bp generated 1,365,298 reads totaling 3,093.3 Mbp of Illumina data. All general aspects of library construction and sequencing performed at the JGI can be found at the JGI user home.

Table 2. Genome sequencing project information for E. arboris LMG $14919^{\top}$.

\begin{tabular}{lll}
\hline MIGS ID & Property & Term \\
\hline MIGS-31 & Finishing quality & Improved high-quality draft \\
MIGS-28 & Libraries used & Illumina Standard (short PE) and Illumina CLIP (long PE) library \\
MIGS-29 & Sequencing platforms & Illumina HiSeq 2000 \\
MIGS-31.2 & Sequencing coverage & Illumina: 448× \\
MIGS-30 & Assemblers & Velvet version 1.1.05; Allpaths-LG version r38445 \\
MIGS-32 & Gene calling methods & Prodigal 1.4, GenePRIMP \\
& GenBank & ATYB00000000 \\
& GenBank release date & July 15, 2013 \\
& GOLD ID & Gi08822 \\
& NCBI project ID & 74465 \\
& Database: IMG & 2512047086 \\
& Project relevance & Symbiotic $\mathrm{N}_{2}$ fixation, ag riculture \\
\hline
\end{tabular}


The initial draft assembly contained 27 contigs in 9 scaffolds. The initial draft data was assembled with Allpaths, version r38445, and the consensus was computationally shredded into $10 \mathrm{Kbp}$ overlapping fake reads (shreds). The Illumina draft data was also assembled with Velvet, version 1.1.05 [31], and the consensus sequences were computationally shredded into $1.5 \mathrm{Kbp}$ overlapping fake reads (shreds). The Illumina draft data was assembled again with Velvet using the shreds from the first Velvet assembly to guide the next assembly. The consensus from the second VELVET assembly was shredded into $1.5 \mathrm{Kbp}$ overlapping fake reads. The fake reads from the Allpaths assembly and both Velvet assemblies and a subset of the Illumina CLIP paired-end reads were assembled using parallel phrap, version SPS 4.24 (High Performance Software, LLC). Possible misassemblies were corrected with manual editing in Consed [32-34]. Gap closure was accomplished using repeat resolution software (Wei $\mathrm{Gu}$, unpublished), and sequencing of bridging PCR fragments using Sanger (unpublished, Cliff Han) technology. For the improved high quality draft, one round of manual/wet lab finishing was completed. A total of 46 additional sequencing reactions, were completed to close gaps and to raise the quality of the final sequence. The estimated total size of the genome is $6.9 \mathrm{Mbp}$ and the final assembly is based on 3,093.3 Mbp of Illumina draft data, which provides an average of $448 \times$ coverage of the genome.

\section{Genome annotation}

Genes were identified using Prodigal [35] as part of the DOE-JGI annotation pipeline [36] followed by a round of manual curation using the JGI GenePRIMP pipeline [37]. The predicted CDSs were translated and used to search the National Center for Biotechnology Information (NCBI) non-redundant database, UniProt, TIGRFam, Pfam, PRIAM, KEGG, COG, and InterPro databases. These data sources were combined to assert a product description for each predicted protein. Non-protein coding genes and miscellaneous features were predicted using tRNAscanSE [38], RNAMMer [39], searches against models of the ribosomal RNA genes built from SILVA [40], Rfam [41], TMHMM [42], and SignalP [43]. Additional gene prediction analysis and manual functional annotation was performed within the Integrated Microbial Genomes (IMG-ER) platform [44].

\section{Genome properties}

The genome is 6,850,303 nucleotides with $62.02 \%$ GC content (Table 3) and comprised of 7 scaffolds (Figure 3) of 12 contigs. From a total of 6,545 genes, 6,461 were protein encoding and 84 RNA only encoding genes. The majority of genes $(80.78 \%)$ were assigned a putative function whilst the remaining genes were annotated as hypothetical. The distribution of genes into COGs functional categories is presented in Table 4 .

Table 3. Genome Statistics for Ensifer arboris LMG $14919^{\top}$

\begin{tabular}{lrr}
\hline Attribute & Value & \% of Total \\
\hline Genome size (bp) & $6,850,303$ & 100.00 \\
DNA coding region (bp) & $5,921,899$ & 86.45 \\
DNA G+C content (bp) & $4,248,771$ & 62.02 \\
Number of scaffolds & 7 & \\
Number of contigs & 12 & \\
Total gene & 6,545 & 100.00 \\
RNA genes & 84 & 1.28 \\
rRNA operons & 3 & 0.05 \\
Protein-coding genes & 6,461 & 98.72 \\
Genes with function prediction & 5,287 & 80.78 \\
Genes assigned to COGs & 5,233 & 79.95 \\
Genes assigned Pfam domains & 5,438 & 83.09 \\
Genes with signal peptides & 588 & 8.98 \\
Genes with transmembrane helices & 1,456 & 22.25 \\
CRISPR repeats & 0 & \\
\hline
\end{tabular}


LMG 14919 : SinarDRAFT scaffold1.7

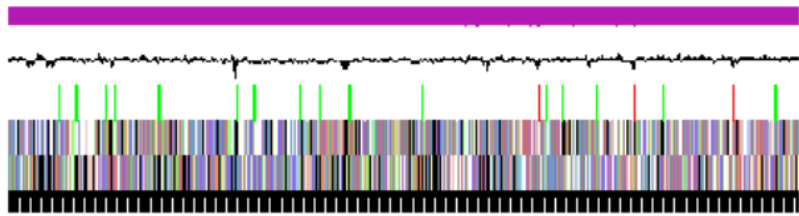

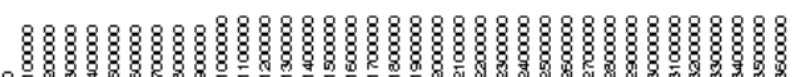

LMG 14919 : SinarDRAFT scaffold2.3

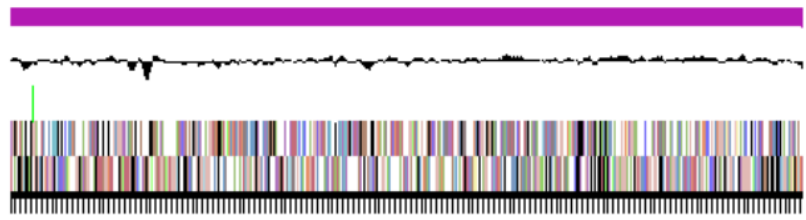

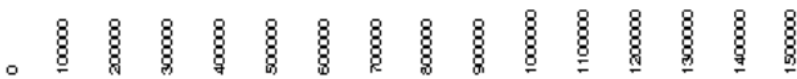

LMG 14919 : SinarDRAFT scaffold3.5

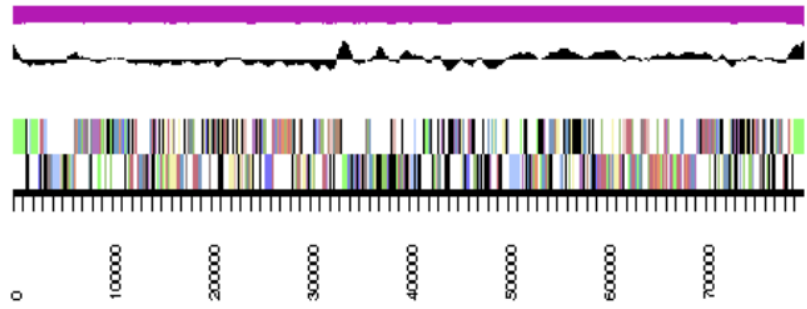

LMG 14919 : SinarDRAFT scaffold4.4

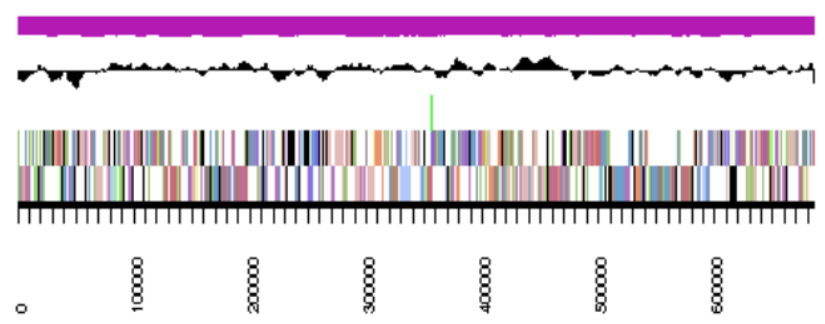

LMG 14919 : SinarDRAFT scaffold5.2
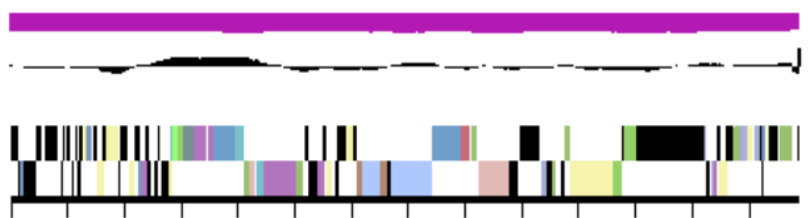

8

Figure 3. Graphical map of the genome of Ensifer arboris LMG $14919^{\top}$ showing the seven largest scaffolds. From bottom to the top of each scaffold: Genes on forward strand (color by COG categ ories as denoted by the IMG platform), Genes on reverse strand (color by COG categ ories), RNA genes (tRNAs g reen, sRNAs red, other RNAs black), GC content, GC skew.

LMG 14919 : SinarDRAFT scaffold6.1

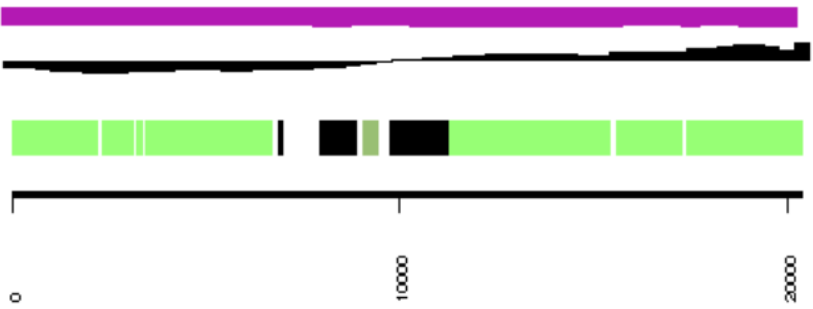

LMG 14919 : SinarDRAFT scaffold7.6

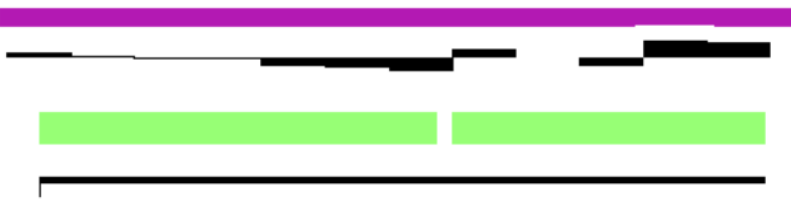

\begin{tabular}{|c|c|}
\hline COG Code & COG Function Definition \\
\hline$[\mathrm{A}]$ & RNA processing and modification \\
\hline [B] & Chromatin structure and dynamics \\
\hline [C] & Energy production and conversion \\
\hline [D] & Cell cycle control, cell division, chromosome partitioning \\
\hline$[\mathrm{E}]$ & Amino acid transport and metabolism \\
\hline$[\mathrm{F}]$ & Nucleotide transport and metabolism \\
\hline$[\mathrm{G}]$ & Carbohydrate transport and metabolism \\
\hline$[\mathrm{H}]$ & Coenzyme transport and metabolism \\
\hline [ [l] & Lipid transport and metabolism \\
\hline$[\mathrm{J}]$ & Translation, ribosomal structure and biogenesis \\
\hline$[\mathrm{K}]$ & Transcription \\
\hline [L] & Replication, recombination and repair \\
\hline$[\mathrm{M}]$ & Cell wall/membrane/envelope biogenesis \\
\hline$[\mathrm{N}]$ & Cell motility \\
\hline [O] & Posttranslational modification, protein turnover, chaperones \\
\hline$[\mathrm{P}]$ & Inorganic ion transport and metabolism \\
\hline [Q] & Secondary metabolites biosynthesis, transport and catabolism \\
\hline$[\mathrm{R}]$ & General function prediction only \\
\hline$[\mathrm{S}]$ & Function unknown \\
\hline$[\mathrm{T}]$ & Signal transduction mechanisms \\
\hline$[\mathrm{U}]$ & Intracellular trafficking, secretion, and vesicular transport \\
\hline$[\mathrm{V}]$ & Defense mechanisms \\
\hline$[\mathrm{W}]$ & Extracellular structures \\
\hline$[\mathrm{Y}]$ & Nuclear structure \\
\hline$[\mathrm{Z}]$ & Cytoskeleton \\
\hline [NA] & Not Assigned \\
\hline
\end{tabular}

http://standardsingenomics.org 
Table 4. Number of protein coding genes of Ensifer arboris LMG $14919^{\top}$ associated with the general COG functional categ ories.

\begin{tabular}{|c|c|c|c|}
\hline Code & Value & $\%$ age & Description \\
\hline$J$ & 195 & 3.35 & Translation, ribosomal structure and biogenesis \\
\hline A & 0 & 0.00 & RNA processing and modification \\
\hline K & 510 & 8.76 & Transcription \\
\hline $\mathrm{L}$ & 212 & 3.64 & Replication, recombination and repair \\
\hline B & 1 & 0.02 & Chromatin structure and dynamics \\
\hline $\mathrm{D}$ & 49 & 0.84 & Cell cycle control, mitosis and meiosis \\
\hline Y & 0 & 0.00 & Nuclear structure \\
\hline V & 60 & 1.03 & Defense mechanisms \\
\hline $\mathrm{T}$ & 248 & 4.26 & Signal transduction mechanisms \\
\hline M & 274 & 4.71 & Cell wall/membrane biog enesis \\
\hline $\mathrm{N}$ & 77 & 1.32 & Cell motility \\
\hline Z & 0 & 0.00 & Cytoskeleton \\
\hline W & 0 & 0.00 & Extracellular structures \\
\hline$U$ & 122 & 2.10 & Intracellular trafficking and secretion \\
\hline $\mathrm{O}$ & 185 & 3.18 & Posttranslational modification, protein turnover, chaperones \\
\hline $\mathrm{C}$ & 349 & 6.00 & Energy production conversion \\
\hline G & 598 & 10.27 & Carbohydrate transport and metabolism \\
\hline $\mathrm{E}$ & 653 & 11.22 & Amino acid transport metabolism \\
\hline $\mathrm{F}$ & 104 & 1.79 & Nucleotide transport and metabolism \\
\hline $\mathrm{H}$ & 201 & 3.45 & Coenzyme transport and metabolism \\
\hline I & 205 & 3.52 & Lipid transport and metabolism \\
\hline$P$ & 292 & 5.02 & Inorg anic ion transport and metabolism \\
\hline Q & 182 & 3.13 & Secondary metabolite biosynthesis, transport and catabolism \\
\hline $\mathrm{R}$ & 721 & 12.39 & General function prediction only \\
\hline S & 582 & 10.00 & Function unknown \\
\hline- & 1,312 & 20.05 & Not in COGS \\
\hline
\end{tabular}

\section{Acknowledgements}

This work was performed under the auspices of the US Departm ent of Energy's Office of Science, Biological and Environmental Research Program, and by the University of California, Lawrence Berkeley National Laboratory under contract No. DE-AC02-05CH11231, Lawrence Livermore National Laboratory under Contract No. DEAC52-07NA27344, and Los Alamos National Laboratory under contract No. DE-AC02-06NA25396. 


\section{References}

1. Deans JD, Diag ne O, Nizinski J, Lindley DK, Seck M, Ing leby K, Munro RC. Comparative growth, biomass production, nutrient use and soil amelioration by nitrog en-fixing tree species in semi-arid Seneg al. For Ecol Manage 2003; 176:253-264. http://dx.doi.org/10.1016/S0378-1127(02)00296$\underline{7}$

2. Ag roforestree Database.

http://www.worl dag roforestrycentre.org/resources /databases/ag roforestree

3. Nick G, de Lajudie P, Eardly BD, Suomalainen S, Paulin L, Zhang X, Gillis M, Lindstrom K.

Sinorhizobium arboris sp. nov. and Sinorhizobium kostiense sp. nov., isolated from leg uminous trees in Sudan and Kenya. Int I Syst Bacteriol 1999;

49:1359-1368. PubMed http://dx.doi.org/10.1099/00207713-49-4-1359

4. Young JM. The genus name Ensifer Casida 1982 takes priority over Sinorhizobium Chen et al. 1988, and Sinorhizobium morelense Wang et al. 2002 is a later synonym of Ensifer adhaerens Casida 1982. Is the combination "Sinorhizobium adhaerens" (Casida 1982) Willems et al. 2003 legitimate? Request for an Opinion. Int I Syst Evol Microbiol 2003; 53:2107-2110. PubMed http://dx.doi.org/10.1099/ijs.0.02665-0

5. Zhang X, Harper R, Karsisto M, Lindstrom K. Diversity of Rhizobium bacteria isolated from the root nodules of leg uminous trees. Int J Syst Evol Microbiol 1991; 41:104-113.

6. Räsänen LA, Lindström K. Effects of biotic and abiotic constraints on the symbiosis between rhizobia and the tropical leg uminous trees Acacia and Prosopis. Indian / Exp Biol 2003; 41:11421159. PubMed

7. Field D, Garrity G, Gray T, Morrison N, Seleng ut J, Sterk P, Tatusova T, Thomson N, Allen M, Ang iuoli SV, et al. Towards a richer description of our complete collection of genomes and metagenomes "Minimum Information about a Genome Sequence " (MIGS) specification. Nat Biotechnol 2008; 26:541-547. PubMed http://dx.doi.org/10.1038/nbt1360

8. Woese CR, Kandler O, Wheelis ML. Towards a natural system of organisms: proposal for the domains Archaea, Bacteria, and Eucarya. Proc Natl Acad Sci USA 1990; 87:4576-4579. PubMed http://dx.doi.org/10.1073/pnas.87.12.4576

9. Garrity GM, Bell JA, Lilburn T. Phylum XIV. Proteobacteria phyl. nov. In: Garrity GM, Brenner DJ, Krieg NR, Staley JT (eds), Bergey's Manual of
Systematic Bacteriology, Second Edition, Volume 2, Part B, Springer, New York, 2005, p. 1.

10. Garrity GM, Bell JA, Lilburn T. Class I. Alphaproteobacteria class. nov. In: Garrity GM, Brenner DJ, Krieg NR, Staley JT (eds), Bergey's Manual of Systematic Bacteriology, Second Edition, Volume 2, Part C, Springer, New York, 2005, p. 1.

11. Validation List No. 107. List of new names and new combinations previously effectively, but not validly, published. Int I Syst Evol Microbiol 2006; 56:1-6. PubMed http://dx.doi.org/10.1099/ijs.0.64188-0

12. Kuykendall LD. Order VI. Rhizobiales ord. nov. In: Garrity GM, Brenner DJ, Kreig NR, Staley JT, editors. Bergey's Manual of Systematic Bacteriology. Second ed: New York: Springer - Verlag; 2005. p 324.

13. Skerman VBD, McGowan V, Sneath PHA. Approved Lists of Bacterial Names. Int J Syst Bacteriol 1980; 30:225-420. http://dx.doi.org/10.1099/00207713-30-1-225

14. Conn HJ. Taxonomic relationships of certain nonsporeforming rods in soil. I Bacterio/ 1938; 36:320-321.

15. Casida LE. Ensifer adhaerens gen. nov., sp. nov.: a bacterial predator of bacteria in soil. Int J Syst Bacteriol 1982; 32:339-345. http://dx.doi.org/10.1099/00207713-32 -3-339

16. Judicial Commission of the International Committee on Systematics of Prokaryotes. The genus name Sinorhizobium Chen et al. 1988 is a later synonym of Ensifer Casida 1982 and is not conserved over the latter genus name, and the species name 'Sinorhizobium adhaerens' is not validly published. Opinion 84. Int I Syst Evol Microbiol 2008; 58:1973. PubMed http://dx.doi.org/10.1099/ijs.0.2008/005991-0

17. Agents B. Technical rules for biological agents. TRBA (http://www.baua.de): 466 .

18. Ashburner M, Ball CA, Blake JA, Botstein D, Butler $\mathrm{H}$, Cherry JM, Davis AP, Dolinski K, Dwight SS, Eppig JT, et al. Gene ontology: tool for the unification of biology. The Gene Ontology Consortium. Nat Genet 2000; 25:25-29. PubMed http://dx.doi.org/10.1038/75556

19. Howieson JG, Ewing MA, D'antuono MF. Selection for acid tolerance in Rhizobium meliloti. Plant Soil 1988; 105:179-188. http://dx.doi.org/10.1007/BF02376781 
20. Beringer JE. R factor transfer in Rhizobium leguminosarum. J Gen Microbiol 1974; 84:188198. PubMed http://dx.doi.org/10.1099/00221287-84-1-188

21. Terpolilli JJ. Why are the symbioses between some genotypes of Sinorhizobium and Medicago suboptimal for $\mathrm{N}_{2}$ fixation? Perth: Murdoch University; 2009. 223 p.

22. Tamura K, Peterson D, Peterson N, Stecher G, Nei M, Kumar S. MEGA5: Molecular Evolutionary Genetics Analysis using Maximum Likelihood, Evolutionary Distance, and Maximum Parsimony Methods. Mol Biol Evol 2011; 28:2731-2739.

$\underline{\text { PubMed }}$ http://dx.doi.org/10.1093/molbev/msr121

23. Nei M, Kumar S. Molecular Evolution and Phylogenetics. New York: Oxford University Press; 2000.

24. Felsenstein J. Confidence limits on phylog enies: an approach using the bootstrap. Evolution 1985; 39:783-791. http://dx.doi.org/10.2307/2408678

25. Liolios K, Mavromatis K, Tavernarakis N, Kyrpides NC. The Genomes On Line Database (GOLD) in 2007: status of genomic and metagenomic projects and their associated metadata. Nucleic Acids Res 2008; 36:D475-D479. PubMed http://dx.doi.org/10.1093/nar/gkm884

26. Galibert F, Finan TM, Long SR, Puhler A, Abola P, Ampe F, Barloy-Hubler F, Barnett MJ, Becker A, Boistard $\mathrm{P}$, et al. The composite genome of the leg ume symbiont Sinorhizobium meliloti. Science 2001; 293:668-672. PubMed http://dx.doi.org/10.1126/science. 1060966

27. Reeve W, Chain P, O'Hara G, Ardley J, Nandesena K, Brau L, Tiwari R, Malfatti S, Kiss H, Lapidus A, et al. Complete genome sequence of the Medicago microsymbiont Ensifer (Sinorhizobium) medicae strain WSM419. Stand Genomic Sci 2010; 2:77-86. PubMed http://dx.doi.org/10.4056/sigs.43526

28. Reeve WG, Tiwari RP, Worsley PS, Dilworth MJ, Glenn AR, Howieson JG. Constructs for insertional mutagenesis, transcriptional signal localization and gene regulation studies in root nodule and other bacteria. Microbiology 1999;

145:1307-1316. PubMed http://dx.doi.org/10.1099/13500872-145-6-1307

29. DOE Joint Genome Institute.

http://my.jgi.doe.gov/general/index.html
30. Bennett S. Solexa Ltd. Pharmacogenomics 2004; 5:433-438. PubMed http://dx.doi.org/10.1517/14622416.5.4.433

31. Zerbino DR. Using the Velvet de novo assembler for short-read sequencing technolog ies. Current Protocols in Bioinformatics 2010; Chapter 11: Unit 115.

32. Ewing B, Green P. Base-calling of automated sequencer traces using phred. II. Error probabilities. Genome Res 1998; 8:186-194. PubMed http://dx.doi.org/10.1101/gr.8.3.175

33. Ewing B, Hillier L, Wendl MC, Green P. Basecalling of automated sequencer traces using phred. I. Accuracy assessment. Genome Res 1998; 8:175-185. $\underline{\text { PubMed }}$ http://dx.doi.org/10.1101/gr.8.3.175

34. Gordon D, Abajian C, Green P. Consed: a graphical tool for sequence finishing. Genome Res 1998; 8:195-202. $\underline{\text { PubMed }}$ http://dx.doi.org/10.1101/gr.8.3.195

35. Hyatt D, Chen GL, Locascio PF, Land ML, Larimer FW, Hauser LJ. Prodigal: prokaryotic gene recog nition and translation initiation site identification. BMC Bioinformatics 2010; 11:119. PubMed http://dx.doi.org/10.1186/1471-2105-11-119

36. Mavromatis K, Ivanova NN, Chen IM, Szeto E, Markowitz VM, Kyrpides NC. The DOE-JGI Standard operating procedure for the annotations of microbial genomes. Stand Genom ic Sci 2009; 1:63-67. PubMed http://dx.doi.org/10.4056/sigs.632

37. Pati A, Ivanova NN, Mikhailova N, Ovchinnikova G, Hooper SD, Lykidis A, Kypides NC.

GenePRIMP: a gene prediction improvement pipeline for prokaryotic genomes. Nat Methods 2010; 7:455-457. PubMed http://dx.doi.org/10.1038/nmeth.1457

38. Lowe TM, Eddy SR. tRNAscan-SE: a prog ram for improved detection of transfer RNA genes in genomic sequence. Nucleic Acids Res 1997; 25:955-964. PubMed

39. Lagesen K, Hallin P, Rodland EA, Staerfeldt HH, Rog nes T, Ussery DW. RNAmmer: consistent and rapid annotation of ribosomal RNA genes. Nucleic Acids Res 2007; 35:3100-3108. PubMed http://dx.doi.org/10.1093/nar/gkm160

40. Pruesse E, Quast C, Knittel K. Fuchs BdM, Ludwig W, Peplies J, Glöckner FO. SILVA: a comprehensive online resource for quality checked and aligned ribosomal RNA sequence data compatible with ARB. Nucleic Acids Res 2007; 35:7188- 
7196. PubMed

http://dx.doi.org/10.1093/nar/gkm864

41. Griffiths-Jones S, Bateman A, Marshall M, Khanna A, Eddy SR. Rfam: an RNA family database. Nucleic Acids Res 2003; 31:439-441. PubMed http://dx.doi.org/10.1093/nar/g kg 006

42. Krogh A, Larsson B, von Heijne G, Sonnhammer EL. Predicting transmembrane protein topology with a hidden Markov model: application to complete genomes. J Mol Biol 2001; 305:567580. PubMed

http://dx.doi.org/10.1006/jmbi.2000.4315
43. Bendtsen JD, Nielsen H, von Heijne G, Brunak S. Improved prediction of sig nal peptides: Sig nalP 3.0. J Mol Biol 2004; 340:783-795. PubMed http://dx.doi.org/10.1016/j.jmb.2004.05.028

44. Markowitz VM, Mavromatis K, Ivanova NN, Chen IM, Chu K, Kyrpides NC. IMG ER: a system for microbial genome annotation expert review and curation. Bioinformatics 2009; 25:2271-2278. PubMed

http://dx.doi.org/10.1093/bioinformatics/btp393 